3 Rogers DB, Shohat M, Pertersen GM, et al. Familial Mediterranean fever in Armenians: autosomal recessive inheritance with high gene frequency. Am J Med Genet 1989;34:168-72.

4 Barakat MH, Karnik AM, Majeed HWA, El-Sobki NI, Fenech FF. Familial Mediterranean fever recurrent hereditary polyserositis in Arabs - a study of 175 patients.and review of the literature. Qf Med 1986;60:837-47.

Cook GC. Periodic disease, recurrent polyserositis, familial Mediterranean fever, or simply "FMF." $Q \mathcal{f}$ Med 1986;60:819-23.

Moore PJ, Mansour A, McDonald JD, Kemp A, Kamath KR, Dorney SFA. Familial Mediterranean fever in six Australian children. Med f Aust 1989;151:108-10.

Mediterran

Gertz MA, Petitt RM, Perrault J, Kyle RA. Autosomal dominant familial Mediterranean fever-like ndrome with amyloidosis. Mayo Clin Proc 1987;62:1095-100.

Melamed A, Cabili S, Zakuth V, Spirer Z. The immune regulation in familial Mediterranean fever (FMF). F Clin Lab Immunol 1988;26:125-8.

9 Matzner Y, Brzezinski A. C5a-inhibitor deficiency in peritoneal fluids from patients with familial Mediterranean fever. $N$ Engl f Med 1984;311:287-90.

10 Shohat $M$, Korenberg JR, Schwabe AD, Rotter JI. Hypothesis: familial Mediterranean fever -A genetic disorder of the lipocortin family? Am F Med Genet 1989;34:163-7.

11 Aisen PS, Haines KA, Given W, et al. Circulating hydroxy fatty acids in familial Mediterranean fever. Proc Natl Acad Sci USA 1985;82:1232-6.

12 Anton PA, Targan SR, Vigna SR, Durham M, Schwabe AD, Shanahan F. Enhanced neutrophil chemiluminescence in familial Mediterranean fever. $\mathcal{F}$ Clin Immunol 1988;8:148-56.

3 Barakat MH, El-Khawad AO, Gumaa KA, El-Sobki NI, Fenech FF. Metaraminol provocative test: a specific diagnostic test for familial Mediterranean fever. Lancet 1984 ; $: 656-7$.

14 Barakat MH, Gumaa KA, Malhas LN, El-Sobki NI, Moussa MA, Fenech FF. Plasma dopamine beta-hydroxylase: rapid diagnostic test for recurrent hereditary polyserositis. Lancet 1988;ii $1280-3$

$1280-3$.

123 I-labelled serum amyloid P component. $N$ Engl f Med 1990;323:508-13.
.

16 Dina Dinarello CA, Wolff SM, Goldfinger SE, Dale DC, Alling DW. Colchici
Mediterranean fever: a double-blind trial. N Englf Med 1974;291:934-7.

17 Zemer D, Revach $M$, Pras $M$, et al. A controlled trial of colchicine in preventing attacks of familial Mediterranean fever. N Engl f Med 1974;291:932-4.

8 Zemer D, Pras M, Sohar E, Modan M, Cabili S, Gafni J. Colchicine in the prevention and treatmen of the amyloidosis of familial Mediterranean fever. N Engl F Med 1986;314:1001-5.

19 Anonymous. Colchicine in amyloidosis [Editorial]. Lancet 1986;ii:724-5.

\section{The fetal and infant origins of adult disease}

\section{The womb may be more important than the home}

A hundred years ago, when tuberculosis and rheumatic heart disease were common, the proposition that the childhood environment affects adult health would have been self evident. This proposition may still hold, even though infective disease has given place to degenerative disease.

Studies in Norway, Finland, Britain, and the United States have shown that death rates from cardiovascular disease are inversely related to adult height, and geographical differences in cardiovascular mortality are related to past differences in infant mortality. ${ }^{1-7}$ These findings have been interpreted as evidence that adverse living conditions during childhood, such as poor housing and diet, increase the risk of ischaemic heart disease. ${ }^{4}$ Case-control studies have generally supported this ${ }^{8-12}$ : patients with myocardial infarction have higher infant death rates among their siblings,${ }^{89}$ are more likely to come from larger families, and are more likely to have fathers who were unemployed. ${ }^{10}$ Now studies in Finland show that men with ischaemic heart disease had worse socioeconomic conditions in childhood $(\mathrm{p} \mathrm{1121})^{12}$ - an observation also made in Britain. ${ }^{9}$

The completeness of infant mortality records in England and Wales from 1911 onwards has allowed detailed geographical comparisons of the relation between infant mortality 70 years ago and mortality from cardiovascular disease today. Differences in the death rates from cardiovascular disease among the 212 local authority areas of England and Wales are closely related to past differences in neonatal mortality. ${ }^{613}$ Most neonatal deaths were associated with low birth weight, and rates were high in areas where mothers had poor health and high death rates during childbirth. ${ }^{14}$ These findings suggested that research should be redirected towards the intrauterine environment rather than the environment in later childhood-housing, family income, diet, and other influences. The Medical Research Council employed a historian to search for old records of birth and infancy. In Hertfordshire health visitors recorded the birth weight of all babies born in the county from 1911 onwards and visited their homes periodically throughout infancy. Follow up studies of the men and women born 60 and more years ago show that those who weighed more at birth and, if they were breast fed, at 1 year, had lower death rates from ischaemic heart disease and stroke. ${ }^{16}$ The differences in death rates were large.

We are beginning to identify processes that link fetal and infant growth with cardiovascular disease. A recent study of 449 men and women aged 50 years who had been born in one hospital in Preston, England, showed that their current blood pressure and risk of hypertension were strongly related to their placental and birth weight. ${ }^{17}$ Pressures were highest when birth weight had been lower than expected from placental weight. Discordance between placental and birth weights may be interpreted as fetal growth failure. Its causes are unknown, but maternal nutrition is an obvious suspect.

These epidemiological findings point to the importance of long term programming in early life and parallel findings in clinical and animal research. For example, the composition of infant food has been shown to have an important effect on motor development in preterm babies, ${ }^{18}$ and programming of lipid metabolism by early feeding has been shown in baboons. ${ }^{19}$ Knowledge of the fetal processes that may determine programming is beginning to emerge. ${ }^{20} \mathrm{~A}$ recent symposium heard evidence that diseases other than cardiovascular disease may also be determined by the maternal environment. ${ }^{21}$ Schizophrenia and obstructive lung disease are two examples.

The old model of adult degenerative disease was based on the interaction between genes and an adverse environment in adult life. The new model that is developing will include programming by the environment in fetal and infant life.

D J P BARKER

Director,

MRC Environmental Epidemiology Unit,

University of Southampton,

Southampton General Hospital,

Southampton SO9 4XY

1 Waaler HT. Height, weight and mortality. The Norwegian experience. Acta Med Scand 1984;679(suppl): 1-56.

2 Notkola V. Living conditions in childhood and coronary heart disease in adulthood. Helsinki: Finnish Society of Science and Letters, 1985.

3 Marmot MG, Shipley MJ, Rose G. Inequalities in death specific explanations of a general pattern? Lancet 1984; ; : 1003-6.

4 Forsdahl A. Are poor living conditions in childhood and adolescence an important risk factor for arteriosclerotic heart disease? British fournal of Preventive and Social Medicine 1977;31:91-5.

5 Barker DJP, Osmond C, Golding J. Height and mortality in the counties of England and Wales. Ann Hum Biol 1990;17:1-6.

6 Barker DJP, Osmond C. Infant mortality, childhood nutrition and ischaemic heart disease in England and Wales. Lancet 1986;i:1077-81.

Buck C, Simpson H. Infant diarrhoea and subsequent mortality from heart disease and cancer. $\mathcal{f}$ Epidemiol Community Health 1982;36:27-30.

Rose G. Familial patterns in ischaemic heart disease. British fournal of Preventive and Social Medicine 1964;18:75-80.

Coggon DNM, Margetts B, Barker DJP, et al. Childhood risk factors for ischaemic heart disease and stroke. Paediatric and Perinatal Epidemiology 1990;4:464-70.

10 Burr ML, Sweetnam PM. Family size and paternal unemployment in relation to myocardial infarction. $\mathcal{F}$ E pidemiol Community Health 1980;34:93-5.

$11 \mathrm{Hasle} \mathrm{H}$. Association between living conditions in childhood and myocardial infarction. BMf 1990;300:512-3.

12 Kaplan GA, Salonen JT. Socioeconomic conditions in childhood are associated with ischaemic heart disease during middle age. $B M 7$ 1990;301:1121-3.

13 Barker DJP, Osmond C, Law C. The intra-uterine and early postnatal origins of cardiovascular disease and chronic bronchitis. $\mathcal{F}$ Epidemiol Community Health 1989;43:237-40.

14 Campbell JM, Cameron D, Jones DM. High maternal mortality in certain areas. London: HMSO, 1932. (Ministry of Health reports on public health and medical subjects, No 68).

15 Barker DJP, Osmond C. Death rates from stroke in England and Wales predicted from past maternal mortality. BMF 1986;295:83-6.

16 Barker DJP, Winter PD, Osmond C, Margetts B, Simmonds SJ. Weight in infancy and death from ischaemic heart disease. Lancet 1989;ii:577-80.

17 Barker DJP, Bull AR, Osmond C, Simmonds SJ. Fetal and placental size and risk of hypertension in adult life. $B M \mathcal{1}$ 1990;301:259-62.

18 Lucas A, Morley R, Cole TJ, et al. Early diet in preterm babies and developmental status at 18 months. Lancet 1990;335:1477-81.

19 Mott GE, Lewis DS and McGill HC, Jr. Programming of cholesterol metabolism by breast or formula feeding. In: Bock GR, Whelan J, eds. The childhood environment and adult disease. Chichester: John Wiley and Sons (in press). (Ciba Foundation symposium No 156.)

20 Dawes GS, Zacutti A, Borruto F, Zacutti A, Jr. Fetal autonomy and adaptation. Chichester: John Wiley and Sons, 1990

21 Bock GR, Whelan J, eds. The childhood environment and adult disease. Chichester: John Wifey and Sons (in press). (Ciba Foundation symposium No 156.) 